\title{
Civilizational Influence of Gaza City in the Ayyobi and Mamluki Periods(567-922ah/1172-1517ad)
}

\author{
D. Gassan Mahmud Weshah* \\ Head of History and Archeology Department__ Islamic University Of Gaza
}

*Corresponding Author:D. Gassan Mahmud Weshah,Head of History and Archeology Department at the Islamic University of Gaza.

\begin{abstract}
The General Idea:

The city of Gaza is one of the oldest historical cities in the world. It was founded by the Canaanite Arabs who came from the Arabian Peninsula in the third millennium BC. The city has a cultural role in Islamic history. This study focuses on the cultural role of Gaza City during the Ayyubid and Mamluki periods.
\end{abstract}

\section{INTRODUCTION}

Gaza is one of the most important and oldest Palestinian cities in particular, and the cities of the world in general. Gaza has been a prominent presence in many areas throughout Islamic history, and Gaza has played an important role in terms of its important geographic position and in terms of historical events that occurred on its territory.

This city has a long history of battles and championships and decisive victories that have succeeded in Gaza, and it is important in the graduation of scientists, and it has significant commercial progress.

Gaza is one of the most civilized cities in Islamic history, because of the fame and characteristics that characterized it and made it the front, and distinguished Gaza with many important historical events starting from the Islamic conquest, and contained many companions scientists and scholars, and Mujahideen.

This research focuses on the cultural role of the city of Gaza in many areas which were famous during an era of history in the Ayyubid and Mamluk periods.

\subsection{The Importance of the Topic}

- The scarcity of studies on this subject, despite its importance.

- Focus on an important aspect of the history of Gaza City in the Ayyubid and Mamluk periods.

- Show the importance of Gaza City in many different areas

- Show the strategic value of Gaza from the Levant

- Knowledge of the components of life in Gaza.

\subsection{Study Approach}

It is the Historical analytical approach.

\subsection{Study Divisions}

This research is divided into an introduction and five main sections and a conclusion:

The first title speaks about the geographical profile of Gaza City, the second is about the religious status of Gaza, and the third address is the economic life of Gaza in the Ayyubid and Mamlukpiriods. The fourth address deals with the military side of Gaza. The fifth title speaks about the urban life in the city of $\mathrm{Z}$ Ayyubid and Mamluks. The conclusion was summarized in the main ideas which reached by the researcher in addition to the list of sources and references. 


\section{FIRST: A GeOgraphical ProfiLe}

The city of Gaza is the nearest Levant to Egypt, it is wide, many architecture, beautiful markets, and many mosques, and walls. ${ }^{1}$ It is located west of Ashkelon ${ }^{2}$ near Jerusalem. Its size is average. It has vineyards on the coast, small orchards and palms, and between it and the sea, sand piles on its orchards and a small fortress, the water is delicious in some wells, and the air is pure. ${ }^{3}$

It is located in the citadel of al-Daroum, through which man can see the sea. It was demolished by Salah al-Din in $584 \mathrm{AH} / 1188 \mathrm{AD}^{4}$ It is built with stone and lime. It is built on a high hill on the Mediterranean coast.

People drink water from wells, and have a complex of rain and have many fruits, including grapes and figs, and a hospital. ${ }^{5}$

Gaza has gained a great geographical position since ancient times. It was located on the most ancient commercial roads in the ancient world, which started in the cities of Yemen. The country's trade and the commerce of India meet and then travel northward to Mecca, Medina and Baghdad, and from there to two branches, one in Gaza on the Mediterranean, While going north to Damascus and Palmyra. ${ }^{6}$

\section{SeCond: The Religious Status of Gaza City}

The importance of the city of Gaza, located between the Levant and Egypt on the edge of Egypt, stems from the famous saying: "I promise you of the two beauties: Gaza and Ashkelon. ${ }^{7 "}$ Itis is not a text of the Prophet (peace and blessings of Allaah be upon him). , It was the birthplace of Imam Muhammad bin Idris al-Shafi'i, who was born in $150 \mathrm{AH}(767 \mathrm{AD})^{8}$. Gaza took its holiness from the holiness of the land of the Levant in general, and Palestine in particular, from the verse, God Almighty said:

"سبحان الذي أسرى بعبده ليلا من المسجد الحرام إلى المسجد الأقصى الذي باركنا حوله لنريه من آيتا إنه هو السميع البصبر"9

Which means:

Glory to (Allah) Who did take His servant for a Journey by night from the Sacred Mosque to the farthest Mosque, whose precincts We did bless,- in order that We might show him some of Our Signs: for He is the One Who heareth and seeth (all things).

Some of the books went on to say that Gaza has taken its importance because it is from the areas of Ashkelon, and they said that Gaza and Ashkelon are one place, since they are adjacent and Ashkelon is the origin of the old time, which is the city, if he said Shafei (Gaza) had wanted the village, and if he said (Ashkelon) he wanted the city.

Among the virtues of Gaza is what was narrated from Mus'abibnThabit from Ibn al-Zubayr: "Blessed is he who dwelt in one of the villages of Ashkelon and Gaza." If the story is correct, it is one of the best cities adjacent to Beit-Maqdis. It is said that our master peace be upon him was born, The Prophet (peace and blessings of Allaah be upon him) and the Imam al-Shaafa'i.

And Gaza occupies this status to embrace the tomb of Hashem bin Abdul Mnaf grandfather of the Prophet peace be upon him, who died during one of the summer trips, and called Gaza Hashim proportion to him, as it is seen that the father of the Prophet Abdullah had a day went out in his trade to the Levant, God be upon him Gaza before the revelation to him when the city was important to the merchants of Mecca, ${ }^{10}$

\footnotetext{
${ }^{1}$ IbnBatoutta,). Journey of Ibn Battuta $\{23\}$

${ }^{2}$ Hamawi, the leader of countries, $\{4 / 204\}$

${ }^{3}$ Assakhawi, Al Buldaneiat, $\{231\}$

${ }^{4}$ Hamawi, the leader of countries $\{4 / 202\}$

${ }^{5}$ Alomare, masalikAlabsar, $\{3 / 552\}$

${ }^{6}$ Shorrab, Alma'alem, $\{209\}$

${ }^{7}$ Mosnad Ahmed, $\{21 / 65\}$

${ }^{8}$ Alqazwini, news of the lands, $\{90\}$

9 AL'ESRA' $\{1\}$

${ }^{10}$ AL'aref, the history of gaza, $\{114\}$
} 


\subsection{Based on the Above, the Religious Status Acquired by the City of Gaza is due to Several Factors, most Notably}

- It is the first city to open in Palestine and may be the first in the Levant.

- On its territory was the first battle fought by the Muslims against the Romans in one of its villages.

- I received the blessed Holy Land blessed by God Almighty, especially adjacent to the Holy House and Al-Aqsa Mosque.

- The birth and residence of Imam Shafei, one of the four imams in the doctrines of jurisprudence.

- Incubation of many companions of the Prophet who lived in its fold.

- Gaza has been mentioned in many religious texts with good and blessings.

\subsection{Islamic Conquest of Gaza City}

Gaza is one of the first cities in which battles took place between the Romans and Muslims, in the succession of Abu Bakr, may Allah be pleased with him, led by the opening Amribn al-Aas before he opened Sebastia and Nablus, where he gave them the safety of themselves and their money, And their homes.

Some books say: It was opened by Mu'awiyahibn Abi Sufyan, and Amribn al-'Aas also opened Rafah. $^{11}$

It is clear that Abu Bakr's collection of all the fighters before the opening of Gaza, which is the gate of the Levant, where he gathered the Muslims and told them that he wants to achieve what the Prophet peace be upon him to open the Levant

Abu Bakr gathered the army, and sent four armies to the Levant opened, where Gaza was in the forefront of the cities to which the army of Muslims and this demonstrates the intelligence of the Caliph, who was sure that the opening of the Levant gate Gaza, which is the Prophet's Prophet peace be upon him before his death .

On the ground of Gaza, the first battle took place between the Muslims and the Romans in a village called Dathan. The two sides fought hard, until the Muslims won. This battle was with the beginning of the Islamic conquest that reached Damascus and Sham, and the first war of war between the Muslims and the Romans. ${ }^{12}$

\subsection{The victory of the Muslims on the Romans for Several Factors, including}

- Tightness and the Gazans' fear of the Roman rule, which was controlled by them, and despised them, and wanted to get rid of it.

- near the inhabitants of Gaza Arab Arabs of the Muslim Arab conquerors, because they were like them, which led to the cooperation of the parties to eliminate and defeat the Romans

- Helping the people of Gaza to conqueror Muslims in the field of roads and geography

- The determination of the Arabs in Gaza to get rid of the oppression, injustice and taxes imposed on them by the Romans.

Some books mention that the first city opened by Amribn al-Aas is the city of Gaza, where Muslims were able to open it with the help of the Arab tribes and they were oppressed under the rule of the Roman rule, which was in 1334 AH. They opened the city and then moved to the_Palestinian cities The other, and believes that Gaza was opened in $19 \mathrm{AH} .^{13}$

It is likely that the first saying that Gaza was opened in $13 \mathrm{AH} / 634 \mathrm{AD}$ is because this date is the closest to sending the Muslim armies to open the Levant, by the Caliph Abu Bakr, may Allah be pleased with him, and Gaza was the gateway to open the Levant, Most of them were in the era of Abu Bakr al-Siddiq, may Allah be pleased with him, and the battle of Yarmouk was the last battles that

\footnotetext{
${ }^{11}$ Albalathri, fotuholbuldan, $\{1 / 164\}$

${ }^{12}$ Hamawi, the leader of countries, $\{2 / 417\}$

${ }^{13}$ IbnAssasakir, Alfutuh, $\{2 / 48\}$ 
took place in the time of Abu Bakr may Allah be pleased with him, where was at the end of his reign and the beginning of the era of Omar ibn al-Khattab may Allah be pleased with him, it is said that the Prophet peace be upon him had sent Osama Bin Zaid to the land of Palestine and specifically the region of Darom in Gaza, and this supports the first novel that confirms that Abu Bakr May Allah be pleased with him sought to make efforts to go to the opening of Palestine, and then to open the rest of the Levant, also confirms that the location of the distinctive geographical Gaza because it is the gateway to the Levant; all of this necessitates the opening of Gaza before other Levant.

\section{Third: The Economic Life of the City of Gaza in the Ayyubid And Mamluk Ages}

In the Ayyubid and Mamluk periods, Gaza lived in distinct economic life due to its excellent geographical location. Commercial convoys were passing through Gaza and because Gaza was a coastal city, which made it a huge tourist activity. The people from all over the world, especially the people of the Arabian Peninsula, Yemen and Africa, Gaza is an important station in commercial flights to Syria and Egypt. Gaza is considered a commercial and cultural center. There were many farms, pastures and all that benefit people by land and sea. Gaza was the point of contact between Egypt, the Levant and the Arabian Peninsula.

Gaza is an agricultural and industrial city. Its main crops are barley, citrus and fruits such as grapes, figs, strawberries and watermelons. The most important fields of industry in Gaza are the textile industry of wool and wool, carpets, carpets, mats, dyeing, embroidery, soap, pottery, tiles, sesame oil and others. ${ }^{14}$

Therefore, there is almost unanimity in the historical sources that we mentioned that Gaza was famous for agriculture, most notably fruit trees and fruits and others.

This has had a significant impact on the promotion of industry and trade in the region, especially when books speak of tree-filled roads and Gaza as green. This confirms that Gaza was fertile agricultural land filled with trees and that agriculture was active.

During the Ayyubid and Mamluk periods, Gaza was characterized by a strong economic life. This was evident in the keenness of the governors and presidents to increase economic power for several reasons:

- land fertility; which is rich in various agricultural crops, fruits and fruit trees

- The important geographical location overlooking the Mediterranean coast, which makes it easy to export goods

- Moderate climate that causes the success of diverse agricultural crops

There are many markets in Gaza, notably: perfume market, grocery, butcher shop, carpentry, copper and others

And spread pottery factories and soap factories and was dominated by the people of agriculture because of the large number of farms that exceed one and a half dunums. ${ }^{15}$

Gaza is an economic market for all convoys because it is the first city on the edge of the desert on the road to the convoys to Egypt, Gaza is the center that brings together the Muslim pilgrims going to Mecca coming to Gaza as a way to travel,

The convoys of trade were meeting in it from all directions to Egypt and to the south of the Arab countries.

The trade was transferred to Gaza by caravans from the area of Aqaba, and achieved a great economic prosperity for Gaza, as well as characterized by Gaza with the presence of many olive presses and sesame and the textile industry and fabrics and the availability of machinery, and had a market known as the textile market

The merchants were living in Cairo, they went to Gaza for trade, and exported large quantities of soap to Egypt, and exported barley to Europe, and had many bathrooms and archaeological lands. ${ }^{16}$

\footnotetext{
${ }^{14}$ Attaba', Ethafol'a'ezza, $\{67\}$

${ }^{15}$ Attaba', Ethafol'a'ezza, $\{271\}$ 
It is clear from the above that the goods in the Gaza markets and the many trades and industries that Gaza was of great economic, agricultural and commercial value, which led to the revitalization of economic life, making it a target for traders coming from the world, especially Egypt adjacent to Gaza directly, The prosperity of the economic life of Gaza during the Mamluks The visit of King AlZaherBaybars ${ }^{17}$ to it several times, where he liked to catch, and Gaza was a center of money during the Mamluk era, where he had a currency worth (eighty of them Badrhm), and then became transactions Alditar, , And measuring its land by Islamic measure. ${ }^{18}$

Although Gaza during the Mamluks was a great city where the deputy Sultan lived and was often visited by the Sultan himself and gives princes and men precious gifts and luxury clothes, and sets the tables. Despite the wealth, but they lost economic losses through the taxes that were taken from its people for the Hurb and aid and the construction of mosques and large buildings,

Rulers were richer because of the taxes they were taking from people,

The economic life in Gaza was affected by the many wars that the Mamluks waged against each other. The jeeps were passing through Gaza, where I camped for each passenger and the point of contact, and Gaza was the supply station in terms of food, drink, meat and vegetables and preparation for war. ${ }^{19}$

Therefore, Gaza, despite the taxes imposed on its people as a result of the orders of the Mamluk rulers and princes, but it was an important commercial and economic center in the forefront of the cities of the Levant because of its geographical location linking the Levant and Egypt, and evidence of the prosperity of economic life of Gaza, what Ibn Battuta said in his trip He said that he visited Hebron and found a marble embossed on the tomb that he allegedly told Ibrahim that he was engraved in Gaza and then transferred to Hebron.

This is a testimony to the prosperity of the economic life of Gaza in the field of marble industry, its inscription and its export to other regions.

\section{Fourth: The Military Side of Gaza City in the Ayyubid and Mamluk AgeS}

\subsection{Gaza in the General Military Scene}

Gaza was characterized by many advantages that made it of great importance in the eyes of the conquerors of kings and leaders of the rulers because it is on the edge of the Levant with Egypt, and because of the high location and high towers, and the strength of fortification, and the height of its castle full of weapons, and because of the strength of its people and immunity of the five doors, : Bab al-Bahr, the gate of the castle to the east, the door of the Darum south, the door of DeirSnyid north, Bab al-Jaran.

Gaza was a major role in all the wars that took place in Palestine, or between Egypt and the Levant, which is the Kingdom of Gaza during the Abbasid period and King Dahliz. It is said that its ruler (the prince, the deputy, the deputy governor and the sponsor). ${ }^{20}$

The city of Gaza has played an important role in the military aspect of the Ayyubid and Mamluk times, especially as it is at the forefront of the Mujahideen and Almorabeen on the Palestinian, Shami and Egyptian borders to protect them from the land and sea assaults of the Romans and to participate in the attacks on the Romans by land and sea. ${ }^{21}$

Gaza is characterized by great military importance because it was the link between Egypt and the Levant, and was the covetous kings in the occupation, because it is the gate of the Levant, and because it is important economically and commercially between Asia and Africa.

The Arabs planned a lot to get some of the coastal areas in the Levant, most notably Gaza, they built on their shores the fortresses, they called it Arbatat, and Rabat is: the observation center where the

\footnotetext{
${ }^{16}$ The source above $\{99\}$

${ }^{17}$ (AzzaherBaibersRoknoddeenAssalehiAl'la'iRlated to his teatcher 'ala'oddeenAlbunduqar, then Najmodden, The fourth of the leaders of Mamluki period, He started to be the leader after Qutz has dide in 658AH/1260Ad)

${ }^{18}$ Amaqrizi,Assuluk, $\{1 / 481\}$

${ }^{19} \mathrm{Al}$ 'aref, The history of Gaza, $\left\{166 \_170\right\}$

${ }^{20}$ Attaba', Ethafol'a'ezza $\left\{260 \_261\right\}$

${ }^{21}$ AbuArrub, the history of palestine, $\{188\}$
} 
soldiers are watching the Roman ships that come to the coast, and the Rabat tower high where a group of men They illuminate the minaret when the Roman ships arrive and then alert the Muslims, and they face the ships with their weapons.

Saladin tried to liberate it repeatedly. He attacked Gaza in 565 AH (1170 AD) and demolished a section of the city and some of its neighborhoods. He was unable to take over the village where the Crusaders had barricaded themselves, And rebuilt it (Baldwin II), and attacked Salah al-Din areas of Ashkelon and Ramle and Gaza in the year (568 AH / 1173 AD)

It is clear from the above that the great immunization built by the Crusaders in Gaza during the occupation of this shows that the city is characterized by an important military area and strategic location influential, and tried hard to fight the Muslims coming to Fftha led by Salahuddin. ${ }^{22}$

The crusaders entered into a treaty with the Muslims, after which they tried to take over Gaza, but they failed. They lost a large number of their soldiers in a battle that took place in $636 \mathrm{AH} / 1239 \mathrm{CE}$. The Muslims killed three of the Crusader leaders and the Muslims captured a large number of their leaders.

In $641 \mathrm{AH}$ (1244 AD), a fierce battle took place on the land of Gaza, where the Crusaders lost 30,000 soldiers and Muslims killed a number of Crusader leaders and captured a large number of them. The Crusader kingdom collapsed after this battle. ${ }^{23}$

The Crusaders defeated the Crusaders in the battle of Hattin in 583 AH / 1187 AD, and continued his victories until welcomed by Gaza. A treaty was signed between Richard the Lionheart, who was residing in Gaza and Salah al-Din in 589 AH / 1193 AD, This agreement striped Gaza of its fortifications and means of defense, and the Convention was implemented strictly.

\subsection{Gaza in the Eyes of the Crusaders}

With the beginning of the first Crusade in (489 AH / 1096 AD) was the most area reached by the Crusaders in the south is Ashkelon, and Gaza remained behind the battlefield in this campaign, while the Crusaders defeated the Egyptians and defeated them in Ashkelon, and the Egyptians returned to their country, and when the Crusaders entered the country in (493 AH / 1100 AD). They moved towards Gaza and rebuilt the fortress. They did not care about it commercially. They made Ashkelon the main center of Nazareth in Palestine. They did not care about it militarily, and they did not make it a military center even though it was walled. In the area of Darom, which is located in the south and made it a fortress for them From Egypt. ${ }^{24}$

With the advent of the Second Crusade came Baldwin III and took care of Gaza and built a large fortress, and was intended to control the Egyptian side and the protection of the Kingdom of Jerusalem, and control of commercial convoys, and ended the construction of the fort in $(545 \mathrm{e} / 1150$ $\mathrm{m}$ ), while the city was fortified and attention to more On the military side, Gaza was a refuge for the Christians in (549 AH / 1154 AD), which Idrissi described as a holy city, populated by people, controlled by the Romans and a port. Salahuddin entered Gaza twice, the first time when Egypt was conquered. He could not fully capture it but s M entering a second time after his victory at the Battle of Hattin.

\subsection{Gaza in the Eyes of the Mamluks}

Gaza was of great importance in the Mamluk era because it was the first line of defense of the state they had established in Egypt, and there were several battles on its soil. The Mamluks have always sought to control them because they are of great military importance and affect their neighboring state.

Gaza has witnessed a battle between the princes of SalehAyoub and Nasser, who fought against the king, in which the owners of the good king were defeated. Al-Nasir departed from Gaza, and Aktai managed to save the city under the instructions of his leader, $648 \mathrm{AH} / 1250 \mathrm{AD}$ ). Ibn al-Nasir Salah al-Din tried to come to Egypt and managed to occupy the coast to Gaza, but he encountered the armies of Aibek, led by Aktay, and forced him to leave Gaza

\footnotetext{
${ }^{22}$ IbnAl'atheer, Alkamel, $\{9 / 361\}$

${ }^{23} \mathrm{Al}$ 'aref, The history of Gaza $\{134\}$

${ }^{24} \mathrm{Al}$ 'aref, The history of Gaza $\{130\}$ 
In 658 AH (1260 AD) Prince Ruknuddin Beybars succeeded in advancing towards Gaza, which was under the occupation of the Tartars. He went to it and liberated it and expelled the Tartars in the Battle of AinGhalout. Prince Shamsuddin Al Azizi was appointed Emir of Gaza and the Coast

Al-Nasser IbnQalawun had visited it repeatedly, either with the intention of visiting or with the intention of suppressing the fire of sedition. He stayed in Gaza for days or weeks. In $684 \mathrm{AH} / 1285$ $\mathrm{AD}$, Nasser IbnQalawun assigned Prince Izz al-Din Aibek Al-Musalli to transfer his emirate from Karak to Gaza. In Gaza and the coasts

Based on the above, the frequent visits of the rulers of the districts to Gaza with the aim of suppressing sedition and fighting the adversaries, or paying attention to Gaza by appointing one of the greatest military leaders such as IzzedineAybak, is proof that life in Gaza was stable in all its aspects because the rulers visit it to stay

Timur Lank sent some of his leaders to Gaza to examine the situation when he wanted to take over Egypt, when the spies returned to tell him that Egypt can not open from the mainland but needs a naval fleet, and Sultan Faraj bin Barqouq stayed in Gaza for a few days

Gaza was the headquarters of the Mamluk states and the name (Kingdom of Gaza), was composed of several countries, including: Ashkelon, Darom, Arish, Hebron, Jaffa, Beit al-Maqdis, and others. The prince of Gaza was called the King of Princes or the Commander of the Army and had special clothes and a special salary. ${ }^{25}$

\section{FifTh: The Housing Life in GaZa In The AyYubid And MAMluk AgeS}

Gaza City has been attacked and destroyed by the Crusaders over many periods, which led to the stability of Muslims within the walls of the city. Historian IbnHawqel describes the city as medium in size and small fortress. In the Mamluk era, Gaza became very civilized and was established in public buildings such as mosques, Islamic schools and hospitals. Gaza became the destination of the traveler

Gaza has become one of the richest cities of Palestine buildings in the Mamluk era, it contains: mosques, hospitals, baths, buildings and shrines, and the attention of the Mamluks in Gaza because it was the center of the country, and the development of the post field in Gaza and this witness to the prosperity of the architectural aspect of that period. ${ }^{26}$

In the Ayyubid period since the beginning of the twelfth century AD that the Muslims were sometimes living outside the city wall, the first urban extension appeared on the east and the neighborhood of Shajaiya, the largest neighborhoods of the city in the present day, ${ }^{27}$

The Mamluks did not care about the western side of the city or the construction of a port. They set up shrines near the sea and established many mosques such as the IbnUthman Mosque., The Mosque of Ibn Marwan, the Ikeki Mosque, the Mosque of Sheikh Qashqar, and Sidra Mosque, and was enlarged Grand Mosque,

The Mamluk baths, known as Hammam al-Samra, were established, and the schools and schools were established. $^{28}$

\subsection{The Architectural Field in the Mamluk Period was Influenced by Several Factors}

- Taking care of the wall of the city to protect it against Crusader attacks.

- The emergence of the first urban extension outside the fence and connects directly with the city, such as Al-Shujaiya neighborhood.

- Take the central urban extension towards the attractions of commercial caravans.

- Economic prosperity, and the increase in population has affected the urban development and public facilities have emerged.

- The streets are narrow, curved and winding

\footnotetext{
${ }^{25} \mathrm{Al}$ 'aref, The history of Gaza $\{130\}$

${ }^{26}$ Gaza Municipality, Outline Plan for the Old Town 1996

${ }^{27}$ Almbaied, Gaza strip, 185

28 'atalla, Anniyaba, \{221_241\}
} 
Many sultans in the Mamluk era, most notably Sultan al-Mansuri, Sultan al-Nasser, Sultan Ibrahim alHajib and Sultan al-Mansur Qalawun, undertook renovations to the mosque and opened new doors to the mosque and raised its courtyard and courtyard to the east, north and west. The winter water for drinking and ablution when needed, and built a mihrab in the eastern Ewan, as well as the establishment of small ewans and renewed the beacon of the call in prayers and lighting in the dawn prayer, and improvements and repairs were made in the large age group inside, Rabe and his pulpit and arches.

It was the headquarters of the Khatib and another of the teacher Sheikh Abdul Majeed al-Bourno, and established a large room was the headquarters of the MaftiShafi'i and the Sheikh of scholars by the time of the mark Mohammed NajibNakhla, and then to the big scientists. ${ }^{29}$

According to the researcher, the great interest in the Omari Mosque demonstrates the interest of the rulers in the mosques, decorating them and decorating them, and enlarging them to accommodate the growing numbers of Muslims. Al-Tabaa mentions that the Umayyad Mosque was praising as a church before the Islamic conquest and then became a mosque after the Christians entered Islam. For any of the sabotage by the Crusaders during their occupation of Gaza. ${ }^{30}$

\subsection{This Information is Likely to be Far from Right for the Following Reasons}

- The Amari Mosque, with its current structure and repairs, can not be maintained without demolition or destruction over more than 1500 years.

- The land of Palestine has been subjected to many wars, earthquakes and lightning in that era, and it is unlikely that the Umayyad Mosque was handed over from these events.

- History has not recorded that Muslims at the opening of any of the countries converted churches to mosques, even if it was possible to do Omar ibn al-Khattab when he refused to pray in the church in Jerusalem on the day to hand over the keys.

- The author states that the church was converted into a mosque and there was a small cist next to it for those who remained of the Christians on its religion. This is illogical, if we assume that the people of the country have all converted to Islam and not need any church.

- It is unlikely that the Crusaders who are the ones who have caused corruption in the land, and turned the Aqsa Mosque to the stable of horses for fear that they have kept the age of his body and did not change.

It is clear that the Umayyad Mosque was built after the Islamic conquest of Gaza during the reign of Umar ibn al-Khattab, but it was transformed after the crusader occupation into a church. It was built in the Crusader era, and after the liberation of Gaza from the Crusaders,

\subsection{Gaza's Housing Neighborhoods and their Divisions}

\subsubsection{In the Mamlukperiod, Gaza was divided into Four sections}

\section{a) The Area of the Addaraj}

Which has been named because it is brought up from each side, to the height of its location like a stairway to the entrance, or because it was next to the leg of the seven degrees known as the staircase is the origin of Gaza with the locality of olives, and was inhabited by heroes known to the Knights of the Temple during the Crusaders, And the castle was located in the municipality buildings taken by post office and health and nearby, and the tower above the vault overlooking the cemetery, has been sabotaged in the wars that took place in the city, has seen this fertile spot civilized centers of courts and royal and military circles and a large market and a number of mosques and military property. ${ }^{31}$

\footnotetext{
${ }^{29}$ Attaba', Ethafol'a'ezza $\left\{106 \_110\right\}$

${ }^{30}$ The source in the bove.

${ }^{31}$ Attaba', Ethafol'a'ezza $\{95\}$ 


\section{b) The Zaytoon Area}

It was named for the abundance of olive trees in the lands belonging to it from the south and west sides, with mosques, monuments, and the church of Pervarius, and the tomb of the Roman Orthodox. ${ }^{32}$

\section{c) Allettoffah Area}

This was called the apple tree in its vineyards, so it was called the apple grove after the end of the Crusades, and some of the ancient antiquities, including the Ikeki Mosque and the shrine of Sheikh Abek and Sadiq al-Jumakiyah, and included Mahalla many families with science and honor and trade, and most of its people farmers and peasants and Mahalla al-Mashahira, an old lane inhabited by soldiers from the government called (Almashahera). ${ }^{33}$

The housing life in Gaza flourished greatly during the Mamluk period, where they were interested in building schools, mosques, forts, marshestas, baths and horse racing courts. Prince Alamuddin bin Abdullah al-JawaliCreated those architectural buildings. ${ }^{34}$

\section{d) Shajaiya area}

It was attributed to Prince Sanger Al-Shuja'i, who was the Sultanate's deputy in Gaza during the days of King Qalawun and his son, King Al-Nasser. He stayed for more than twenty years and the Prince Al-Shuja'i attributed to the courageous sons of the Arabs, a large camp equal to its size and population half of Gaza. It flourished in urban areas and the large population after the Crusades. It is famous for the large families, including the nervous, courageous, nationalistic, and nationalist. Sometimes the quarrels are fierce, but they soon return to harmony, forgiveness, peace and peace. ${ }^{35}$

\section{RESEARCH RESULTS}

- Gaza is one of the oldest and most ancient Palestinian cities and the cities of the Levant in general.

- The city of Gaza enjoys great religious significance, as mentioned by the Prophet (peace be upon him) in his conversations.

- Gaza is characterized by a geographical location leading and important; its people to be at the top of the cities of the Levant, especially its location between the Levant and Egypt.

- Gaza is the first city opened by the Muslims in the Levant by Amribn al-Aas in the succession of Abu Bakr and on whose land occurred the first Muslim sites with the Romans.

- Gaza is an important commercial center through its coastal location and linking it between the Levant and Egypt.

- Gaza was characterized by a large and important commercial center before Islam, where Hashim visited the grandfather of the Prophet (peace be upon him) and died, and the rest of them Omar bin Al Khattab and other people of the Hijaz.

- Gaza has a great scientific and pioneering position where it embraced many of the most prominent scholars, Imam Shafi'i, may Allah have mercy on them.

- Gaza fought several decisive battles on its territory and was characterized by great military importance as it was the focus of the eyes of the Crusaders and Mamluks.

- Gaza has been characterized by economic prosperity in various agricultural, industrial and commercial fields.

\footnotetext{
${ }^{32}$ Attaba', Ethafol'a'ezza $\{96\}$

${ }^{33}$ The same source $\{98\}$

${ }^{34} \mathrm{He}$ is one of the leaders, He was born in 653AH/1255AD, He was one of the jawel's kings for Azzaherbaibars, Faught with Alkhaleelibnqalawoon, Then he returned to Eypt in Katebgha time, he was the leader of Gaza, For more: Anojom by Ibntigree, Addorar by Ibnhajar, and Husnulmohadara by Al_soyutee.

${ }^{35}$ Attaba', Ethafol'a'ezza $\{99\}$
} 
- Gaza is the land of Ribat and Jihad, where it and Ashkelon cities of Rabat on the Thagor is the best Ribat of the Levant.

- Gaza had a great and important role in the Mamluk era as it was the Deputy Sultan and was the supervisor of many cities, including Damascus and Beit Al-Maqdis.

- The Gaza Strip was characterized by its military fortification and it had the fortress of Darom and its old wall where it confronted many invaders and played a prominent military role.

- In Gaza, there have been many buildings and structures that show the prosperity of urban civilization in the city, most notably mosques, schools, libraries and marastas.

- Gaza flourished in markets and trade, making it a center for traders coming from all regions

\section{SOURCES AND REFERENCES}

[First: The Holy Quran]

\section{Second: Sources:}

[1] Ibn al-Atheer, Abu al-Husayn Ali ibnAbiay al-Qarram al-Jazari, by al-Dayyan al-Atheer (c. $630 \mathrm{AH}$ ).

[2] Al-Dhahabi, Shams al-Din Abu-Abdullah Muhammad ibn Ahmad bin Othman al-Dhahabi (d. 748 AH) SiyyarA'alam al-Nubla, Abu Hajar Muhammad Zaghloul, Beirut,

[3] Al-Sukhawi, Shams al-Din Abu al-Khayribn Muhammad (d. 902). Al-Baldaniyat, Saudi Arabia, Dar AlAttaa. 1422 Hijri.

[4] IbnBatoutta, Mohammed bin Abdullah, Abu Abdullah (d: 770 Hijri). Journey Ibn Battuta, Dar al-Sharq.

[5] The son of Eyas. History of Egypt.

[6] IbnAssasakir, Abu al-Qasim Ali bin al-Hasan bin Heba Allah, (c. 571 Hijri). History of Damascus, Dar alFikr for printing and publishing, 1995.

[7] Al-Baladari, Ahmed bin Yahya bin Jabir (T: Hajri 279). Open the countries, Dar Al-Hilal, Beirut, 1988.

[8] Abkhazari, Aboasak Ibrahim bin Mohammed (T: 346 Hijri). Roads and kingdoms, the General Authority for Culture, Cairo.

[9] Al-Qazwaini, Zakaria bin Mohammed bin Mahmoud (v. 682 Hijri), the country and the news of the slaves, Beirut, Dar Sader

[10] Abu Abbas Alqlqshandi.

[11] Al-Maqrizi. Behavior in the knowledge of the kings.

[12] Al-Maqdisi, Abu Abdullah Muhammad ibn Ahmad, the best in the knowledge of the Territories

[13] Azizi, Hassan bin Ahmed Mahlabi, T: 380 e, tracts and kingdoms.

[14] Idrissi, Mohammed bin Abdullah bin IdrisTalabi, Tel: 560 e, NozhaAlmstaq breakthrough in horizons, Beirut, 1, 1409 e

[15] Hamawi, Shahabuddeen Abu Abdullah Yacout bin Abdullah Al-Roumi Tel: 626 e, the dictionary of countries, Dar Sader, Beirut, 2, 1995

[16] Al-Omari, Ahmad bin Yahya bin Fadl al-Qurashi, Shahabuddin v: 749 e, Pathways of sight in Mamlak, Abu Dhabi 1/1423 AH

[17] Al-AlimiMujair al-Din al-Hanbali, the most important person in the history of Jerusalem and Galilee, achieved by Adnan Yunus plant, Amman, $1420 \mathrm{e}$.

[18] Syrup Mohammed bin Mohammed Sharab, the most famous monuments, in the year and the biography, Dar Al-Qalam, Damascus, I.

[19] Al-Waqqadi, Muhammad ibn Umar ibnWaqid al-Aslami, Abu Abdullah, 207 AH, Al-Maghazi, Beirut, Dar al-Alami, 3, 1989

\section{Third: References}

[20] Aarif, Unknown, History of Gaza, Lights of the predecessor

[21] Dabbagh, Mustafa Marraad, our country Palestine, Dar al-Huda, 1, 2003

[22] Salih, Raed Ahmed Salhahah, Gaza City, A Study in the Geography of Cities, Gaza, 1997

[23] The Palestinian Encyclopedia

[24] Mobiad, Selim, Gaza and its Sector, Cairo, Egyptian General Book Organization, 1987

[25] Mohsen Abdel Karim Hassan, Master Thesis: Architectural Character of Gaza City, Al-Azhar University, Cairo, 2000 
[26] Atallah, Muhammadud, Gaza Prosecution in the Mamluk Period, New Horizons House, Beirut, 1979

[27] Felix, Schmidt Fabry, a Swiss scholar in the fifth century AD

Fourth: Periodicals

[28] Gaza Municipality, Outline Plan for the Old Town, 1996

\section{AUTHOR'S BIOGRAPHY}

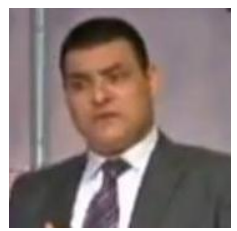

Dr. Ghassan Mahmoud Washah,Head of History and Archeology Department at the Islamic University of Gaza

Citation: D. Gassan Mahmud Weshah. "Civilizational Influence of Gaza City in the Ayyobi and Mamluki Periods (567-922ah/1172-1517ad)”. International Journal of History and Cultural Studies (IJHCS). vol 4, no. 2, 2018, pp. 1-11. doi:DOI: http://dx.doi.org/10.20431/2454-7654.0402001.

Copyright: (C) 2018 Authors. This is an open-access article distributed under the terms of the Creative Commons Attribution License, which permits unrestricted use, distribution, and reproduction in any medium, provided the original author and source are credited. 